\title{
動的計画法による再突入飛行の最適軌道設計*1 Optimal Trajectory Design for Reentry Flight by using Dynamic Programming
}

\author{
原 田 明 徳*2 宮 沢与 和*3
}

Akinori HARADA and Yoshikazu MiYAZAWA

\begin{abstract}
Key Words: Reentry, Optimal Control, Guidance, Optimal Trajectory, Multipurpose Optimization, Dynamic Programming
\end{abstract}
\begin{abstract}
Optimal trajectory design for reentry flight is studied by using Dynamic Programming (DP) method. DP is selected to make use of its ability of generating the optimal trajectory in real time as well as its simplicity to handle inequality constraint conditions for the trajectory optimization. The large amount of calculations to reduce discretization error in case of fewer control variables than the state variables is one of the drawbacks, but it is solved with two proposed techniques of Augmented Control Variables (ACV) method and the Least-error Grid-point Selection (LGS) method.
\end{abstract}

\section{1. は じめに}

スペースシャトルは 2011 年に 30 年間にわたる運用を終 えたが，有翼型の宇宙往還機は有人宇宙活動の基本要素で あり, 将来宇宙輸送システムの研究において検討は続けら れている．特に，宇宙からの帰還における再突入飛行には 空力加熱の問題があり，機体システム設計において基本課 題を残している．機体システムの検討において再突入飛行 の軌道設計は重要な要素であり, 研究の進展のためには設 計条件を変えた数多くの解析を行う必要がある. 本研究は, 軌道最適化の計算を短時間に確実に行うことができる動的 計画法の利点を活かして再突入飛行に応用し, 簡単な例題 を用いてその有効性を検討する.

最適制御問題に対しては古くから変分法による数值解法 が確立しており，一般によく利用される ${ }^{1 \sim 3)}$. 変分法とは Euler-Lagrangeの微分方程式を 2 点境界值問題として解く ものであり, 適当な初期解を定めて繰り返し計算を行う必 要があるため, 初期值や終端条件, 評価関数, 拘束条件の 変更に対して調整を必要とする。また，最近では計算機の 処理能力の向上に伴い, 制御変数や状態変数を有限個の変 数に離散化し, 汎用のパラメータ最適化の数值解析手法を 用いて最適解を求める直接法も使用される3). 近年では少 ない離散点で高精度の解が得られる方法として Pseudospectral法が盛んに研究されている ${ }^{4,5)}$. しかし, 直接 法には, 局所最適解の問題や，与えられた誤差の範囲内に 収めるように反復計算を行うため計算時間が不確実である という久点がある. 再突入飛行の解析ばかりでなく, 誘導 制御システムの設計において, 扱いやすく短時間で確実に 最適軌道を求めることができる最適化の数值解析手法が求

*102012 日本航空宇宙学会

平成 23 年 11 月 17 日, 日本航空宇宙学会西部支部講演会にて発表 平成 24 年 5 月 28 日原稿受付

*2九州大学大学院工学府航空宇宙工学専攻

*3九州大学大学院工学研究院航空宇宙工学部門
められている6 . この要求を満たす方法として動的計画法 (Dynamic Programming, DP) を選択し, 最適制御問題一 の適用可能性について検討する.

動的計画法はHamilton-Jacobi-Bellmanの偏微分方程式を 数值的に解くものであり以下のような利点と欠点を持つ ${ }^{6}$. 利点

(1)システムの状態を有限個の格子点で表し，遷移のすべて の組み合わせを効率よく探索する. 格子点間では繰り返し 計算が不要なため計算量が予測でき, 軌道生成が確実に可 能となる.

(2)すべての組み合わせを調べるため大域的最適解が得られ， 局所最適解の問題が生じない.

(3)状態変数と制御変数に制約条件がある場合でも容易に対 応できる. 制約条件の変化に対して計算法が複雑になるこ とがなく，同じアルゴリズムで解くことができる.

欠点

(1)状態変数を分割することにより離散化誤差が発生する. この離散化誤差を小さくするため分割の方法に工夫を要す る場合がある。

(2)制御変数の個数が状態変数の個数よりも少ない場合, 格 子点を結ぶ解が極端に少なくなり非常に細かい格子が必要 となる。

(3)状態変数の次元が大きくなると計算量，メモリ容量が極 端に増加し計算に旡大な時間を要するようになる。この欠 点は動的計画法を提案したBellmanにより「次元の呪い」と 名付けられた ${ }^{1,3,7)}$.

これらの久点は動的計画法の適用範囲を狭める原因とな っている. しかし，計算機の能力すなわち計算速度および メモリ容量は近年急速に進歩しており，応用範囲の拡大を 追求すべきである. 本研究の目的は, 上記の久点を克服し て動的計画法を適用できる問題の範囲を拡張し, 宇宙往還 機システムの研究推進に貢献することである．特に，欠点 
(2)の制御変数が少なく離散化誤差の抑制が困難な問題に対 する解決方法を提案する.

\section{2. 再突入飛行における最適軌道設計}

現在までに実用化された再使用型宇宙往還機（Reusable Launch Vehicle, RLV) は弾道飛行を行うカプセル回収方式 とスペースシャトルに代表されるような有翼回収方式に 大別される. 両者の大きな違いは, カプセル型RLVの飛行 では加速度が 6G程度と人間の耐えうる限界值に近くなる のに比べ, 有翼型RLVでは揚力を調節することにより $1.5 \mathrm{G}$ 程度に抑えられることである. 本稿では後者による再突入 飛行を対象とする。宇宙空間から地上へ帰還するには, 初 期の大きな力学的エネルギーを空力加熱による熱エネル ギーへ変換することで適切な速度に減速する必要がある. 機体表面は熱防護材で覆われているが，これらの量を抑制 するために機体の受ける加熱量を制限しなければならな い. 空力加熱には速度と空気密度が関係し, 加熱量を小さ くするには速度に適した高度を飛行する必要がある.また, 強度設計の条件より機体にかかる荷重には制限が加わる. これらの条件から回廊と呼ばれる飛行可能な領域が決ま るが，再突入飛行を行う機体は適切な制御によりこの領域 をくぐり抜けることができる，速度に応じた空気密度，す なわち高度をとるためには, 経路角が適切な值となるよう バンク角を調節することで揚力の鉛直方向成分を変化さ せる. バンク角制御にはエレボンなどの空力舵面や姿勢制 御システム (Reaction Control System, RCS) が用いられる. この一連の制御方法は有翼型RLVに特有のものであり, 米 国のスペースシャトル技術において開発された ${ }^{8,9)}$.

2.1 支配方程式 縦の軌道設計において, 以下のよう な質点近似した機体の運動方程式を用いる ${ }^{9 \sim 11)}$.

$$
\begin{aligned}
& \frac{d V}{d t}=-g \sin \gamma-D^{*} \\
& \frac{d D^{*}}{d t}=\left(-\frac{V}{H_{0}} \sin \gamma+2 \frac{\dot{V}}{V}+\frac{1}{C_{D}}\left(\frac{\partial C_{D}}{\partial \alpha} \dot{\alpha}+\frac{\partial C_{D}}{\partial M} \dot{M}\right)\right) D^{*} \\
& \frac{d \gamma}{d t}=\left(\frac{V}{R_{0}+H}-\frac{g}{V}\right) \cos \gamma+\frac{L}{m V} \cos \sigma \\
& こ こ て ゙ \text { 最適化に用いる状態変数は, } \\
& V \quad: \text { 速度 } \\
& D^{*}: \text { 抗力加速度 }(D / m) \\
& \gamma \quad: \text { 経路角 }
\end{aligned}
$$

制御変数は以下のバンク角である.

$\sigma$ : バンク角

迎角 $\alpha$ を制御変数として揚力係数 $C_{L}$ および抗力係数 $C_{D}$ を調 節することも可能ではあるが，機体の表面温度分布は迎角 により決まるので熱防護材の設計の点から, 迎角は 40 度程 度の一定值をとるとする。

他の変数は以下のとおりである.
$L$ : 揚力,
$g$ : 重力加速度, $H$ : 高度,
$m$ : 機体の質量, $R_{0}$ : 地球の半径

大気モデルには，以下のような単純な指数関数モデルを用 いている.

$$
\rho(H)=\rho_{0} \exp \left(-\frac{H}{H_{0}}\right)
$$

$H_{0}$ はスケールハイトと呼ばれる定数である. 重力加速度お よび揚力，抗力は以下の式で与えられる.

$$
\begin{aligned}
& g(H)=g_{0}\left(\frac{R_{0}}{R_{0}+H}\right)^{2} \\
& L=\frac{1}{2} \rho(H) V^{2} S C_{L}(\alpha, M) \\
& D=\frac{1}{2} \rho(H) V^{2} S C_{D}(\alpha, M)
\end{aligned}
$$

2.2 独立変数 運動方程式には状態変数の他に時間の 関数がないので状態変数のうち一つを独立変数とすること ができる. 動的計画法により最適軌道を求める際，単調に 変化する変数を独立変数として最適性の原理を適用する必 要がある．飛行のほとんどで減速することが予想されるの で速度は独立変数として使用できる可能性があるが，深い 経路角の場合，必ずしも減少する訳ではない．無推力の機 体において力学的エネルギーは抵抗によって必ず減少する ので, 力学的エネルギーを独立変数とする方が適当である. 力学的エネルギーは速度とジオポテンシアル高度を用いて 表現できる.これを機体の質量で除し独立変数とする.

$$
E^{*}=\frac{1}{2} V^{2}+g_{0} H_{p}
$$

ジオポテンシアル高度は以下の式で定義される.

$$
H_{p}=\frac{R_{0} H}{R_{0}+H}
$$

変数 $E^{*}$ を独立変数として運動方程式を記述することによ り, 状態変数を一つ減らすことができる. すなわち,

$$
\frac{d E^{*}}{d t}=V \frac{d V}{d t}+g_{0} \frac{d H_{p}}{d t}=-V D^{*}
$$

より, 運動方程式は以下のように 2 つ状態変数によって 記述される。

$$
\begin{aligned}
& \frac{d D^{*}}{d E^{*}}=\frac{\sin \gamma}{H_{0}}+2 \frac{g \sin \gamma+D^{*}}{V^{2}} \\
& \frac{d \gamma}{d E^{*}}=\left(\frac{g}{V}-\frac{V}{R_{0}+H}\right) \frac{\cos \gamma}{V D^{*}}-\left(\frac{C_{L}}{C_{D}}\right) \frac{\cos \sigma}{V^{2}}
\end{aligned}
$$

2.3 飛行軌道制限 飛行可能領域は，あるエネルギー における抗力加速度の上下限值により決定される．以下に 抗力加速度の上下限值の設定方法について説明する。

抗力加速度の上限

抗力加速度の上限值は, 空力加熱率と機体にかかる荷重 の条件から決まる。まず，空力加熱による制限を示す．機 体の表面温度はよどみ点において最高となる，よどみ点に おける曲率半径を $r$ とすると, 空力加熱率の制限は以下の 式で示される.

$$
\frac{d q}{d t}=\frac{C_{q}}{\sqrt{r}} \sqrt{\rho} V^{3} \leq \dot{q}_{\max }
$$

これは空気密度と飛行速度の関数で与えられる簡易なモデ ルである. $C_{q}$ は実験式から得られる空力加熱率係数であり $1.65 \times 10^{-4}\left[\mathrm{Ws}^{3} / \sqrt{\mathrm{kg}} / \mathrm{m}^{3}\right]$ とする ${ }^{9)}$. 空力加熱率の制限值 
$\dot{q}_{\max }$ を $600\left[\mathrm{~kW} / \mathrm{m}^{2}\right]$ と定める ${ }^{9)}$ と, 格子点上のVを用いて $E^{*}$ に対し $\rho$ の上限值が決まり, 抗力加速度 $D^{*}$ の上限值が求め られる．次に荷重条件による制限を示す．空気力は動圧に 比例し, マッ八数と迎角の関数である空力係数に比例する.

$$
F_{N}^{*}=\frac{F_{N}}{m}=\frac{1}{2 m} \rho V^{2} S C_{N}(\alpha, M) \leq F_{N, \max }^{*}
$$

法線方向の空気力による加速度を $F_{N}^{*}$ とし, この制限值 $F_{N, \text { max }}^{*}$ は35[m/s $\left.\mathrm{s}^{2}\right]$ に設定する。(14)式より, 空力特性から 抗力加速度の上限值を与える.

抗力加速度の下限

抗力加速度の下限值は，バンク角ゼロの釣り合い飛行の 条件から導かれる. 寸なわち, 経路角およびその時間変化 率がゼロであることが条件となる，よって，(3)式より

$$
\frac{V^{2}}{R_{0}+H}-g+D^{*}\left(\frac{C_{L}}{C_{D}}\right)=0
$$

となる. (15)式より, 空力特性から抗力加速度の下限值を 与える.

2.4 最適軌道設計 動的計画法を用いて再突入飛行に おける最適軌道を導く. 評価関数 $J$ には空力加熱率を積分 した総加熱量を設定する. (13)式に示す空力加熱率は運動 に影響を及ぼさない量であるので評価関数として扱うこと ができる。

$$
\begin{aligned}
J & =\int_{t_{0}}^{t_{f}} \frac{d q}{d t} d t=\int_{t_{0}}^{t_{f}} \frac{C_{q}}{\sqrt{r}} \sqrt{\rho} V^{3} d t \\
& =\int_{E_{0}}^{E_{f}} \frac{C_{q}}{\sqrt{r}} \sqrt{\rho} \frac{V^{2}}{D^{*}}\left(-d E^{*}\right)
\end{aligned}
$$

最適な評価関数 $J_{o p t}$ は状態変数 $D^{*}, \gamma$ および独立変数 $E^{*}$ の関数であり, $J_{\text {opt }}\left(D^{*}, \gamma, E^{*}\right)$ と表すことができる. 動的計 画法は状態変数を離散化し, 各格子点間における遷移軌道 の組み合わせ最適化問題に帰着させることで最適軌道の近 似解を求めるものである. 動的計画法のアルゴリズムに基 づき, 単調に減少する独立変数 $E^{*} に$ 対し第 1 図のように $\left(D^{*}, \gamma\right)$ を離散化し, 以下の最適性の条件から各格子点間に おける遷移軌道を求める.

$$
\begin{gathered}
J_{o p t}\left(D_{i_{k+1}}^{*}, \gamma_{j_{k+1}}, E_{k+1}^{*}\right) \\
=\min _{\substack{i_{k+1} \rightarrow i_{k} \\
j_{k+1} \rightarrow j_{k}}}\left\{J_{o p t}\left(D_{i_{k}}^{*}, \gamma_{j_{k}}, E_{k}^{*}\right)+\Delta J\left(D^{*}, \gamma, E^{*}\right)\right\} \\
\Delta J=\int_{E_{k+1}^{*}}^{E_{k}^{*}} \frac{C_{q}}{\sqrt{r}} \sqrt{\rho} \frac{V^{2}}{D^{*}}\left(-d E^{*}\right)
\end{gathered}
$$

(17)式の左辺は, 第 1 図に示す $E_{k+1}^{*} \rightarrow E_{k}^{*}$ の遷移において 格子点間のすべての軌道を探索し, 評価関数が最小となる ものを一つ選択することで導かれる． $\left(D^{*}, \gamma\right)$ の遷移を実現 するためには制御変数であるバンク角 $\sigma$ 調節する. 可制 御なシステムにおいては, 制御变数を時間の関数として自 由に動かすことができれば離散化された 2 点間を結ぶこと ができるが，ここではアルゴリズムの複雑化と計算時間の 増大を避けるため一定とする．しかし， 2 次元の格子点間 において制御変数を一定とすると 2 点を結ぶことが不可能 となる.このように制御変数の数が状態変数の数よりも少

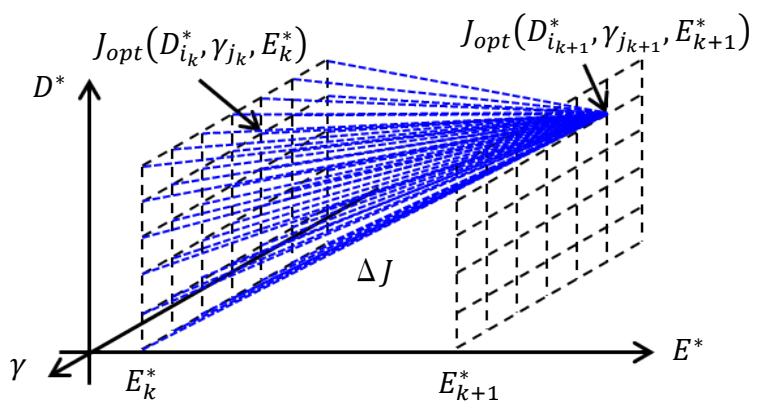

第 1 図 格子点と遷移軌道

ない場合，格子を細かくすると同時に何らかの条件の緩和 を行い，離散化誤差を許容する必要がある，格子を細かく すると計算量が増大寸るので，計算量を抑えつつ工学的に 意味のある最適軌道を求める方法を提案する必要がある.

2.5 補助制御変数法 2 つの格子点を結ぶ解が存在し なければ制御変数 $\sigma$ のみで経路角 $\gamma$ を制御するのは不可能 ということになる．そこで離散化された 2 点間を遷移させ るために制御変数の自由度を緩和する. 具体的には経路角 を調節するための制御変数 $を$ 補助する制御変数として補 助制御変数 $T^{*}$ を導入する。 これは推力を機体質量で除した ものであり系にエネルギーを与える．よって評価関数であ る総加熱量を大きくする効果を持つので最適化の過程にお いて 2 つの格子点を結ぶためだけに必要な最低限の值をと ることが期待される。この值が離散化誤差として許容でき るほど微小であれば得られた軌道は最適軌道となり, 加熱 量においては, 安全側の值を示す。この方法を補助制御変 数法 (Augmented Control Variable, ACV) と呼ぶこととする. 運動方程式(11)式, (12)式に補助制御変数 $T^{*}$ を導入し, 微分 項を差分近似することで以下のような代数方程式を得る.

$$
\begin{gathered}
\frac{\Delta D^{*}}{\Delta E^{*}}=\frac{\left\{-V^{2} \sin \gamma+2 H_{0}\left(-g \sin \gamma+T^{*}-D^{*}\right)\right\} D^{*}}{H_{0} V^{2}\left(T^{*}-D^{*}\right)} \\
\frac{\Delta \gamma}{\Delta E^{*}}=\frac{\left(\frac{V}{R_{0}+H}-\frac{g}{V}\right) \cos \gamma+\left(\frac{C_{L}}{C_{D}}\right) \frac{D^{*}}{V} \cos \sigma}{V\left(T^{*}-D^{*}\right)}
\end{gathered}
$$

これらの 2 式を連立して解くことで，状態空間の 2 点間の

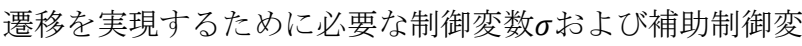
数 $T^{*}$ が求められる.ただし，格子点間の状態量は $2 つ の$ 点 における值の平均值を用いる.

$$
\begin{aligned}
& D^{*}=\left(D_{i_{k}}^{*}+D_{i_{k+1}}^{*}\right) / 2, \quad \gamma=\left(\gamma_{j_{k}}+\gamma_{j_{k+1}}\right) / 2, \\
& E^{*}=\left(E_{k}^{*}+E_{k+1}^{*}\right) / 2
\end{aligned}
$$

また，状態の変化量は以下の差分式により近似する.

$$
\Delta D^{*}=D_{i_{k}}^{*}-D_{i_{k+1}}^{*}, \Delta \gamma=\gamma_{j_{k}}-\gamma_{j_{k+1}}, \Delta E^{*}=E_{k}^{*}-E_{k+1}^{*}
$$

2.6 ACV 法による計算結果 解析に用いる各定数およ び状態変数の初期值は以下のとおりである.

$$
\begin{aligned}
& m=12,000[\mathrm{~kg}], \quad S=50\left[\mathrm{~m}^{2}\right], \quad r=1.0[\mathrm{~m}] \\
& R_{0}=6,368[\mathrm{~km}], \quad \rho_{0}=1.752\left[\mathrm{~kg} / \mathrm{m}^{3}\right]^{9)}, \quad H_{0}=6,700[\mathrm{~m}]^{9)} \\
& C_{L}=0.7, \quad C_{D}=0.7, \quad L / D=1.0, \quad \alpha=45[\mathrm{deg}] \\
& V\left(t_{0}\right)=7,650[\mathrm{~m} / \mathrm{s}] \\
& D^{*}\left(t_{0}\right)=0.98\left[\mathrm{~m} / \mathrm{s}^{2}\right], \quad H\left(t_{0}\right)=80,000[\mathrm{~m}]
\end{aligned}
$$

初期状態量については，経路角のみ自由とし，速度，抗力 加速度，高度については固定する．計算時間を増やさず精 


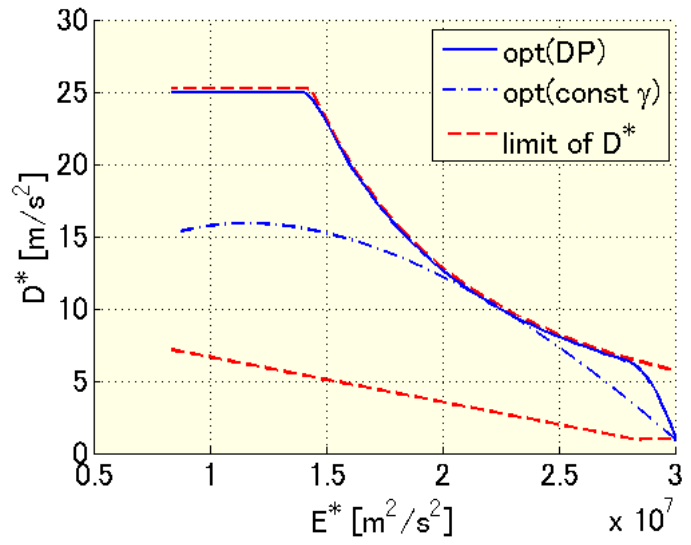

第 2 図 抗力加速度の最適軌道 (ACV 法)

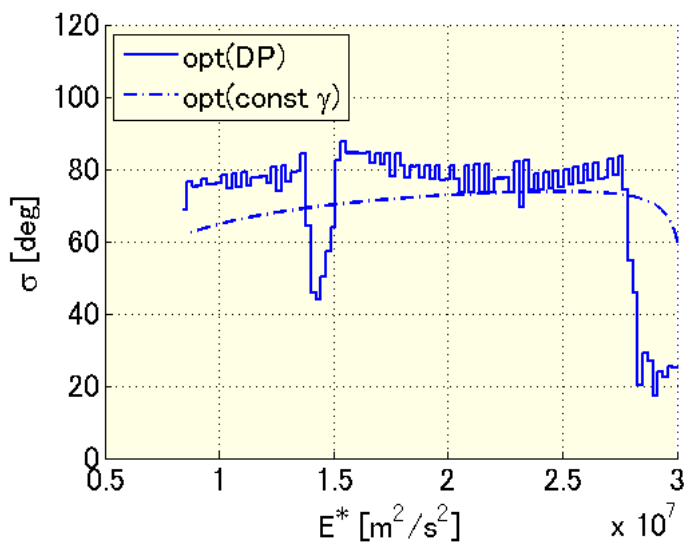

第 4 図 バンク角 (ACV 法)

度のよい結果を得るため, 計算領域を以下のように設定し 離散化を行った.

$$
\begin{aligned}
& D^{*}: 100 \text { 分割 } D_{\text {min }}^{*} \leq D^{*}\left[\mathrm{~m} / \mathrm{s}^{2}\right] \leq D_{\text {max }}^{*} \\
& \gamma: 100 \text { 分割 } \quad \gamma_{\text {min }} \leq \gamma[\mathrm{deg}] \leq \gamma_{\text {max }} \\
& E^{*}: 100 \text { 分割 } \quad E_{\text {min }}^{*} \leq E^{*}\left[\mathrm{~m}^{2} / \mathrm{s}^{2}\right] \leq E_{\text {max }}^{*} \\
& \gamma_{\text {min }}=-2.0, \quad \gamma_{\text {max }}=0, \Delta \gamma=2.0 \times 10^{-2} \\
& E_{\text {min }}^{*}=8.39 \times 10^{6}, E_{\text {max }}^{*}=3.00 \times 10^{7} \\
& \Delta E^{*}=2.16 \times 10^{5}
\end{aligned}
$$

ただし, 差分近似を用いた計算により振動解が発生する恐 れがある。これは状態を大きく恋化させた方が最適解付近 をより細かく調べられ, 評価関数を小さくすることができ るためである．そこで基準のバンク角 $\sigma_{0}$ からのずれを評価 することで離散化誤差による高周波振動を抑えるという工 夫を施す.よって, 以下のように評価関数に振動を抑える 項を追加する.

$$
J=\int_{t_{0}}^{t_{f}}\left\{\frac{C_{q}}{\sqrt{r}} \sqrt{\rho} V^{3}+w_{\sigma} \frac{\left(\sigma-\sigma_{0}\right)^{2}}{d t}\right\} d t
$$

総加熱量のみを評価して振動解が発生した場合, その時 の最適な $\sigma$ をスムージングし, 基準バンク角 $\sigma_{0}$ に設定する. 振動が発生しない範囲で $w_{\sigma}$ の值を小さくしていき, 振動が 発生する場合と比較して総加熱量の值の差が十分小さくな れば，得られた軌道は現実的な最適軌道であると言える.

第 2 図はエネルギーと抗力加速度の最適軌道，第 3 図は 経路角の最適軌道をプロットしたものである。第 4 図およ

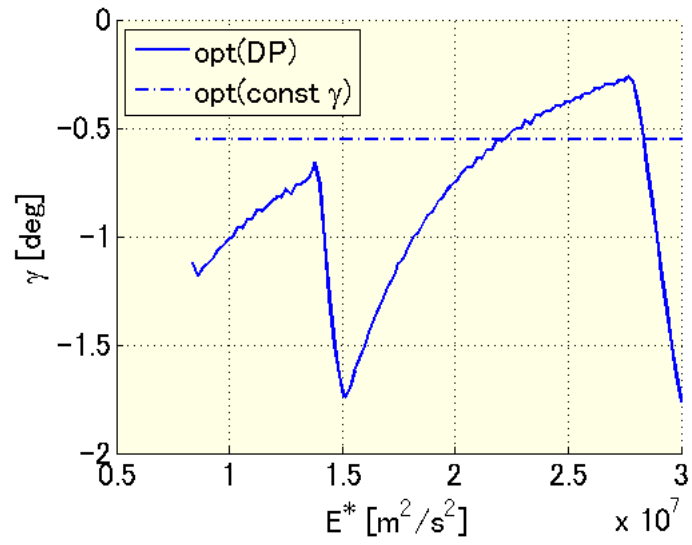

第 3 図経路角の最適軌道（ACV 法）

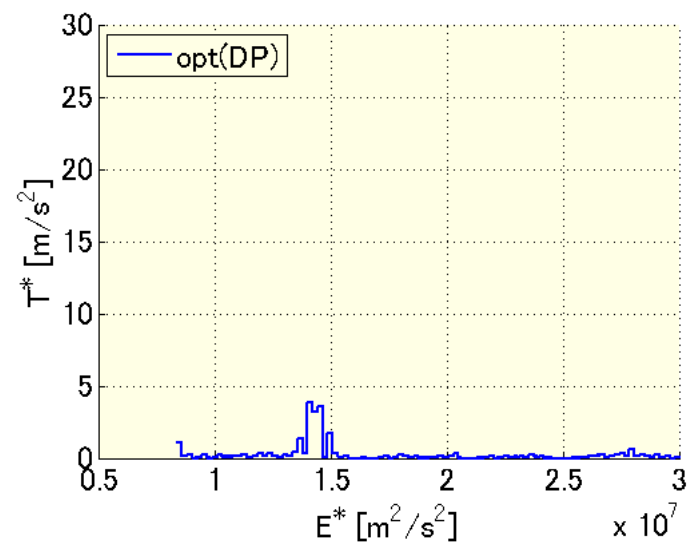

第 5 図 補助推力 (ACV 法)

び第 5 図はバンク角と補助制御変数としての推力の結果で ある。最適制御の一例として一定経路角による飛行を考え るとその最適軌道は一点鎖線で表される．終端における総 加熱量は一定経路角の場合 $198.09\left[\mathrm{MJ} / \mathrm{m}^{2}\right]$ であるのに対し 動的計画法による軌道では $174.34\left[\mathrm{MJ} / \mathrm{m}^{2}\right]$ と約 $12.0 \%$ 削減 された．初期状態から徐々に抗力加速度を増していき空力 加熱の上限に沿って飛行している．荷重制限による上限へ 切り替わる部分では補助推力が多少大きな值をとっている が格子を細かくすることで離散化誤差を許容するために導 入した変数として十分小さな值となる.

補助制御変数として評価関数を悪くする効果を持つ変数 を導入すると，最適化の過程においてこの効果が最小とな る軌道が選択され，工学的に有意な最適軌道を得ることが できる. ACV 法は評価関数への影響が一方的である場合に は有効であるが，多目的最適化問題のように必ずしも補助 制御変数が最小になるとは限らない場合は使うことができ ない，そこで，離散化による誤差の影響を抑えつつ工学的 に意味のある最適軌道を設計する新たな手法を提案する.

2.7 最小誤差格子点選択法 離散化した状態変数によ り構成される状態空間において, 状態の遷移は制御変数の 調節により実現される．ここで，制御変数の個数が状態変 数の個数に比べて少なく 2 つ格子点の間で制御変数を一 定とすると解が存在しなくなる場合の解決方法を提案する.

解くべき運動方程式は(11)式および(12)式から成る連立 方程式であり, 未知数は制御変数 $\sigma$ である. 状態量には 2 
つの格子点の平均值を用いる． $\sigma$ を一定值として解こうと すると，両式を厳密に満足する解は存在しない。これは第 6 図に示すように, 離散化して与えた格子点以外の部分に 解が存在するためである.

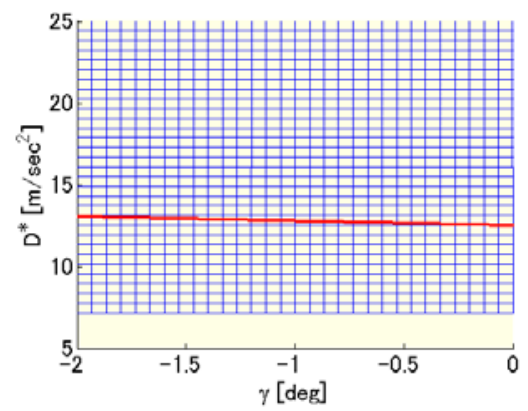

第 6 図＼cjkstart遷移間で $\sigma 一$ 定とした場合の到達可能曲線

第 7 図から第 9 図より，制御変数のバンク角は経路角を 直接制御することができるが，抗力加速度への感度はほと んどない，これは，経路角の変化率はバンク角に，抗力加 速度の変化率は経路角にそれぞれ支配されるからである.

そこで，以下のような手順で近似解を求める．ただし， 微分項には差分近似を適用する.

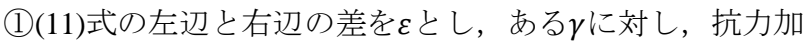
速度の方向にこの值の変化を調べる.

$$
\varepsilon=\frac{\Delta D^{*}}{\Delta E^{*}}-\left(\frac{\sin \gamma}{H_{0}}+2 \frac{g \sin \gamma+D^{*}}{V^{2}}\right)
$$

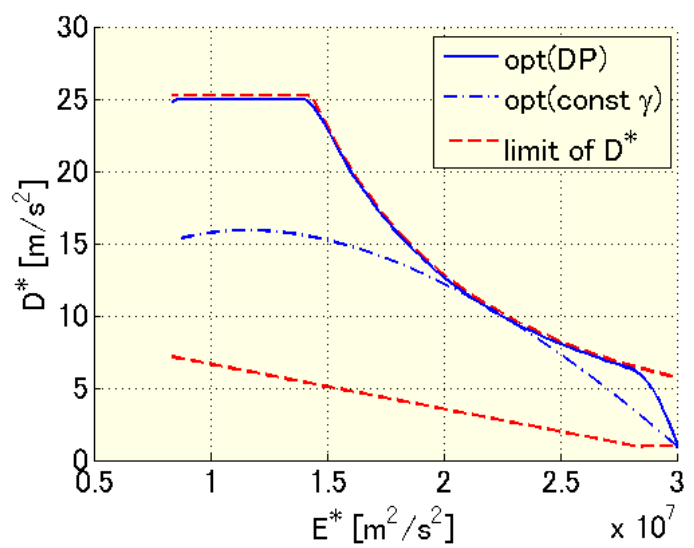

第 7 図 抗力加速度の最適軌道（LGS 法）

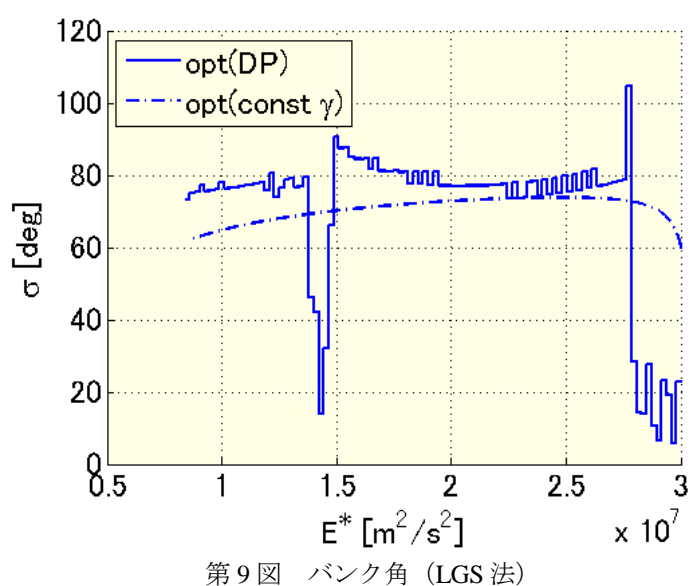

第 9 図 バンク角 (LGS 法)
格子点の間に存在する正解をまたぐとき, $\varepsilon$ の符号が変化す るのでそのような 2 点に着目する.

(2)これらの 2 点に対し $\varepsilon$ の絶対值が小さい方を, 真の解に最 も近い近似解が得られる格子点として採用する.

(3)この格子点を用いて(12)式より $\sigma$ を導く.

$$
\sigma=\cos ^{-1}\left\{\left(g-\frac{V^{2}}{R_{0}+H}\right) \frac{\cos \gamma}{D^{*}}-V^{2} \frac{\Delta \gamma}{\Delta E^{*}}\right\}
$$

与えた格子点の中で正解に最も近い点が得られるという ことで，この方法を最小誤差格子点選択法(Least-error Grid-point Selection, LGS)と呼ぶこととする. この方法の大 きな利点として以下の 2 点が挙げられる.

最小誤差格子点選択法の利点

$>$ 補助制御変数法とは異なり, 微分方程式の誤差が解の 両側にばらつくので，誤差が蓄積されることがなく，

評価関数に複数の最適化条件が含まれる多目的最適化 問題に適用することができる.

> 誤差の大小は格子の分解能にのみ依存するので，分割 数を上げれば解の精度は必ず向上する.

2.8 LGS 法による計算結果 LGS 法の有効性を確認す るため, 総加熱量のみを最小化する単一目的最適化問題を LGS 法で解き, ACV 法の結果と比較する.したがって, 評価関数および計算条件は 2.6 節に示したものと同一とす る.

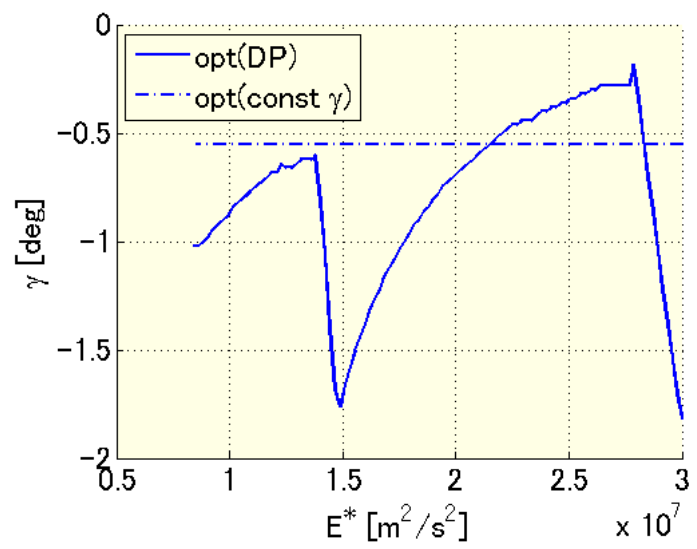

第 8 図経路角の最適軌道（LGS 法）

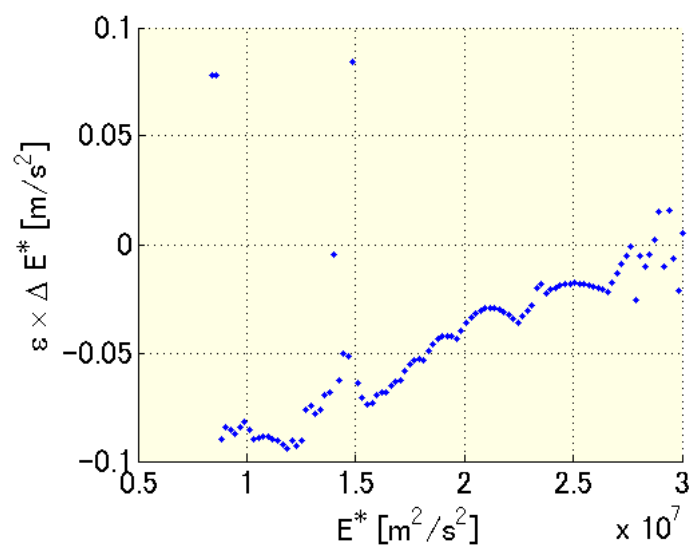

第 10 図微分方程式誤差 (LGS 法) 
第 10 図は微分方程式の誤差であるとに $\Delta E^{*}$ を乗じ, 補助 制御変数 $T^{*}$ の単位と揃えてプロットしたものである. 抗力 加速度および経路角については ACV 法と同様の結果が得 られた。 バンク角については, 空力加熱による限界線に達 するまでの值が, ACV 法の結果と若干異なっている。これ は空気密度が微小な高高度においては揚力がほとんど発生 せず，バンク角を変化させても抗力加速度には影響が及ば ないためであると考えられる。また， $E^{*}=1.5 \times$ $10^{7}\left[\mathrm{~m}^{2} / \mathrm{s}^{2}\right]$ 付近における微分方程式誤差は ACV 法のもの よりも小さいため, 引き起こしを行うための浅いバンク角 は LGS 法の方がより精度よく求められていると言える.

終端における総加熱量は $171.10\left[\mathrm{MJ} / \mathrm{m}^{2}\right]$ となり, 経路角 を一定とした基準軌道と比較すると約 13.6\%削減された.

LGS 法では誤差がゼロのまわりにばらついて分布するた め評価関数によらず離散化誤差の増大を引き起こすことが なく, 格子の分割を細かくすれば解の精度は必ず向上する という点で有効な手段である。これらの性質により多目的 最適化問題においても現実的な最適軌道を設計することが 可能となる.

\section{3. 多目的最適化問題}

3. 1 飛行レンジの追加 LGS 法は ACV 法に比べ誤差が 蓄積されにくいという性質が明らかとなったため, 評価関 数に加熱量ばかりでなく飛行レンジを調節する要素を付加 し, 多目的最適化問題とする. 有翼型 RLV の再突入飛行

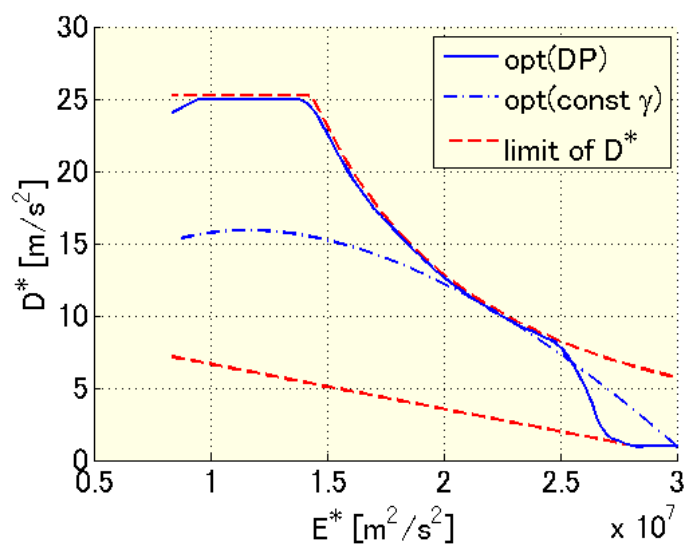

第 11 図 抗力加速度の最適軌道 (多目的最適化)

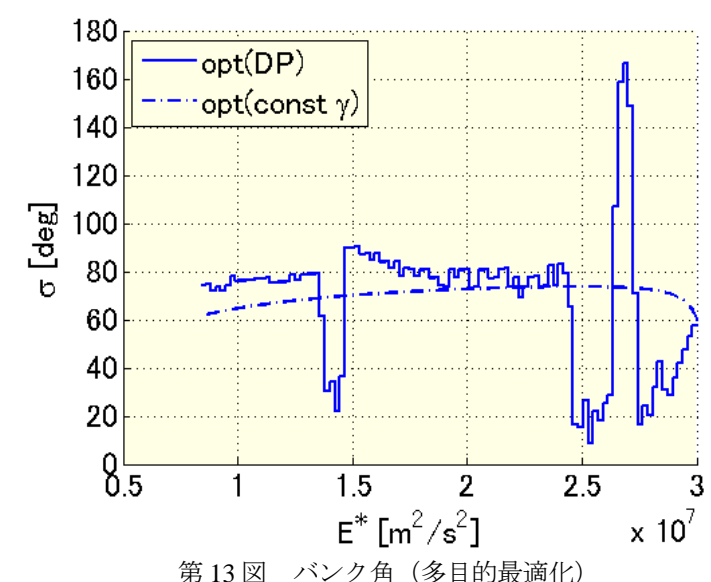

第13図 バンク角 (多目的最適化)
では，到着地点が指定されているため，再突入開始時には 到達可能距離を把握しておくことが必要不可欠となる．経 路角を制御するためにバンク角を調節することから横にず れが生じるが，このずれはバンクリバーサルと呼ばれるバ ンク角の左右を入れ替える操作により修正する。この操作 中は抗力加速度の誘導は行われないが, 短時間であると仮 定して縦の運動には影響が及ばないとする。

レンジR $R_{\phi}$ は次式で定義する.

$$
R_{\phi}=\int_{t_{0}}^{t_{f}} V \cos \gamma d t=\int_{E_{0}^{*}}^{E_{f}^{*}} \frac{\cos \gamma}{D^{*}}\left(-d E^{*}\right)
$$

このレンジに任意の重み程を付加し, 総加熱量と組み合わ せて評価関数とする.

$$
\begin{aligned}
J= & \int_{E_{0}^{*}}^{E_{f}^{*}}\left\{\frac{1}{q_{0}} \frac{C_{q}}{\sqrt{r}} \sqrt{\rho} \frac{V^{2}}{D^{*}}-w_{R} \frac{1}{R_{\phi 0}} \frac{\cos \gamma}{D^{*}}\right. \\
& \left.+w_{\sigma} \frac{\left(\sigma-\sigma_{0}\right)^{2}}{\left(-d E^{*}\right)}\right\}\left(-d E^{*}\right)
\end{aligned}
$$

3.2 計算結果 正規化定数である $q_{0}$ と $R_{\phi 0}$ は, 経路角一 定とした基準軌道に沿って飛行したときの值に設定する.

$$
\begin{aligned}
& q_{0}=198.09\left[\mathrm{MJ} / \mathrm{m}^{2}\right] \\
& R_{\phi 0}=2825.46[\mathrm{~km}]
\end{aligned}
$$

(25)式の重みを $w_{R}=0.38, w_{\sigma}=0.01$ として計算した結果 を第 11 図から第 14 図に示す. 総加熱量のみを評価した 2.8 節の結果と比較すると, $E^{*}=2.5 \times 10^{7}\left[\mathrm{~m}^{2} / \mathrm{s}^{2}\right]$ 付近までは 抗力加速度の下限值に沿って釣合い飛行を行っている点が

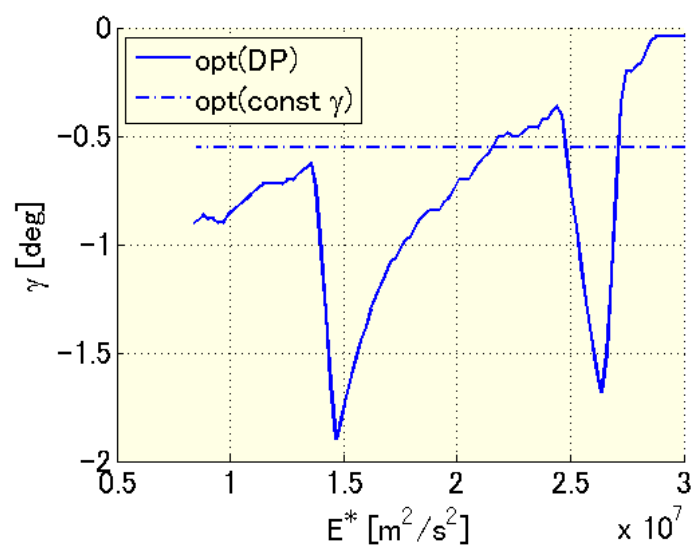

第 12 図経路角の最適軌道(多目的最適化)

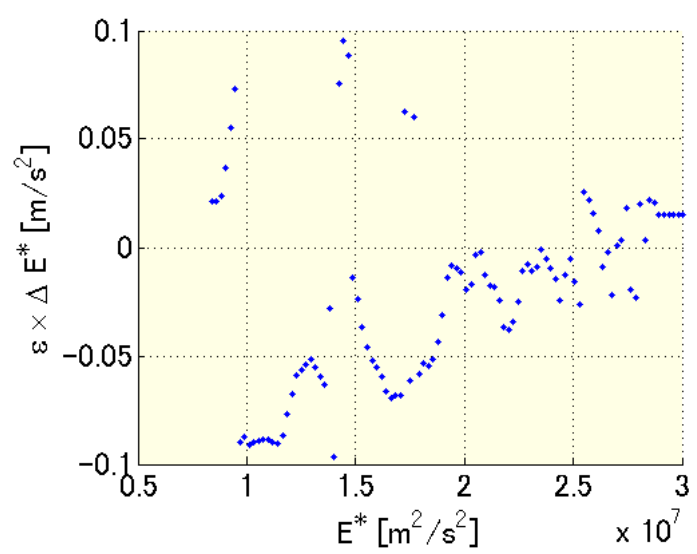

第 14 図 微分方程式誤差（多目的最適化） 
異なる。これは, 空気密度の小さいところでは飛行レンジ を伸ばすためにより大きな揚力を発生させ，その後，最大 の加熱率となる飛行を行って加熱量を最小化しようとする ためである．終端における総加熱量および飛行レンジを第 1 表に示寸. 飛行レンジは, 総加熱量のみを評価した場合 に比べて約 $2300 \mathrm{~km}$ 増加した. 総加熱量も増加しているが, これは飛行レンジとともに評価することで飛行時間が増加 したためである.

\begin{tabular}{ccc} 
& 第 1 表 最適値の比較 & \\
\hline & 単一目的最適化 & $\begin{array}{c}\text { 多目的最適化 } \\
\left(w_{R}=0.38\right)\end{array}$ \\
\hline 総加熱量 $\left[\mathrm{MJ} / \mathrm{m}^{2}\right]$ & 171.10 & 225.75 \\
\hline 飛行レンジ $[\mathrm{km}]$ & 2055.20 & 4357.97 \\
\hline
\end{tabular}

次に, 重み $w_{R}$ の值を変化させた場合について検討を行っ た．第 15 図より， $w_{R}$ を大きくすると総加熱量および飛行 レンジはともに増加することが分かる．機体の質量に占め る熱防護材の質量の限界值から，設計要求として終端にお ける総加熱量の最大值が決まるので, それに応じて到達可 能距離としての飛行レンジを導くことができる.

第 16 図は重み $W_{R}$ に対するそれぞれの最適軌道を重ねて 図示したものである. 小さい $w_{R}$ では総加熱量を重く評価す るため, 抗力加速度は上限值を取る部分が多いが， $w_{R}$ を大
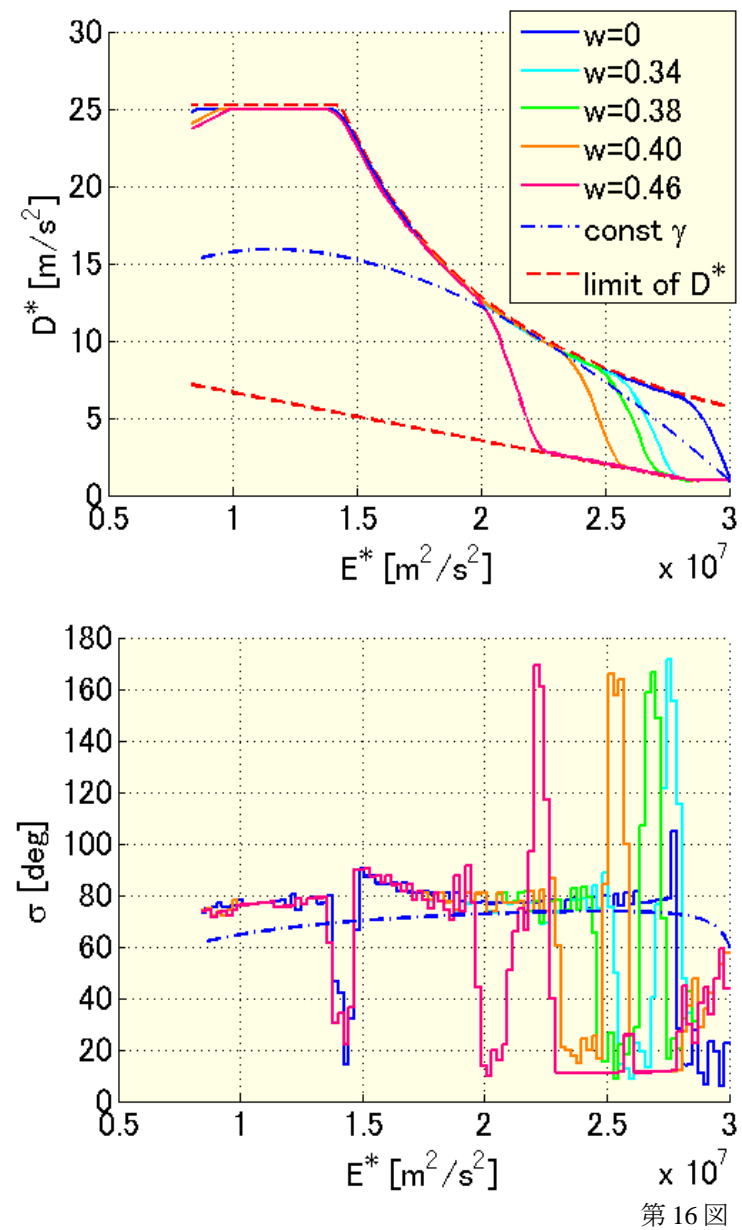

第16図重み秋 $\boldsymbol{R}$ と最適軌道の結果
きくすると飛行レンジを伸ばすため, 抗力加速度の下限值 に沿って釣合い飛行を行う部分が多くなる傾向がある. $w_{R}$ を増やすと浅い経路角で飛行する部分が多くなるが，経路 角を深くして抗力加速度の上限值へと遷移した後は加熱量 を小さくするため，どの $w_{R}$ についても同様の軌道となる. 最適軌道はエネルギーを保持して飛行レンジを伸ばすフェ ーズとエネルギーを熱として消費するフェーズに分かれて おり，その間を遷移するタイミングはどちらを重く評価す るかによって決まる。また，バンク角については遷移する 部分で $170^{\circ}$ 程度となり, 背面飛行を行って最速で抗力加

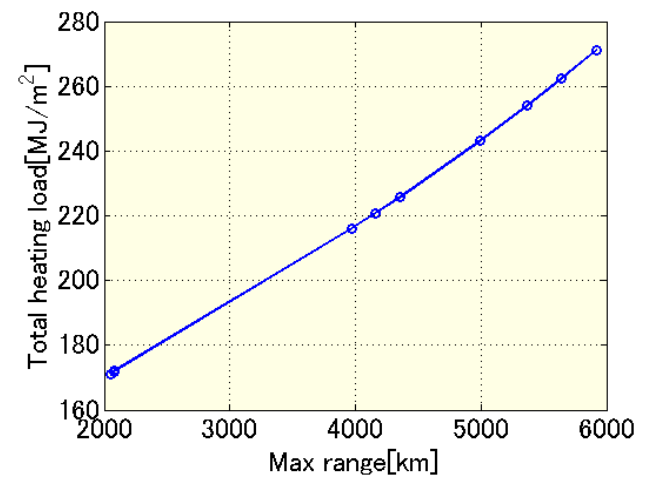

第 15 図 最小総加熱量と最大飛行レンジの関係
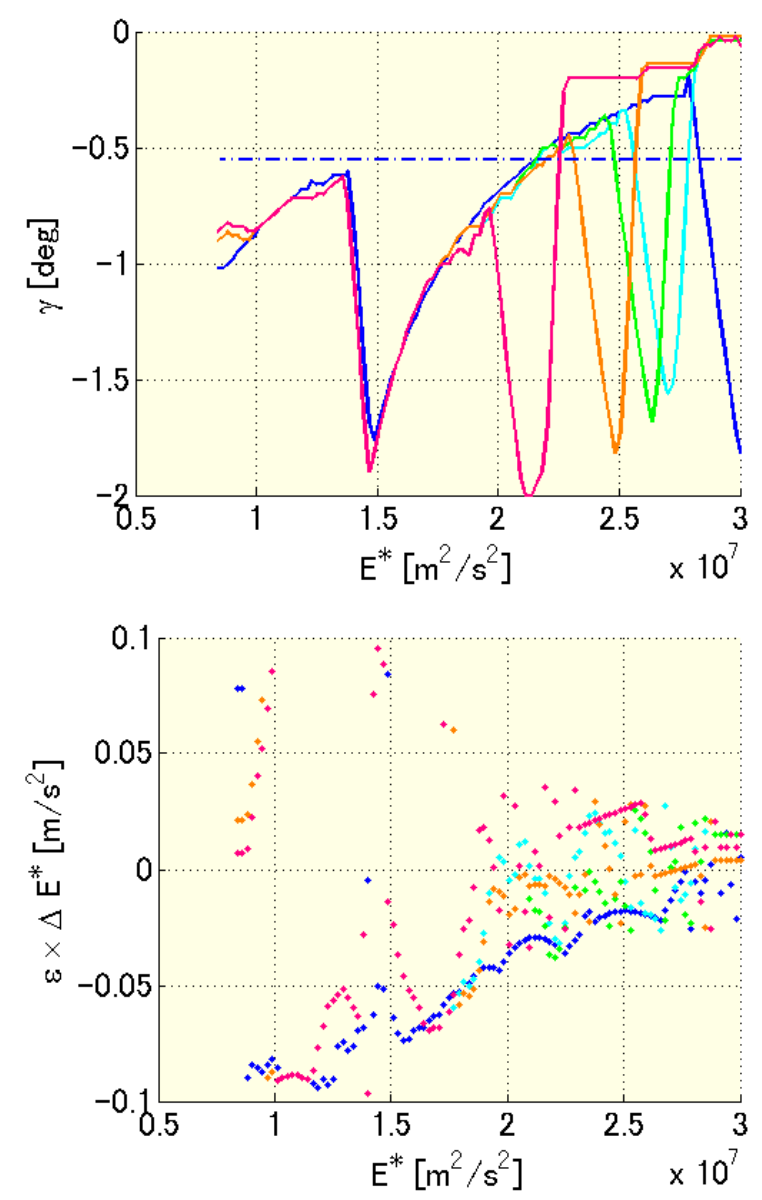
航空宇宙技術 第 11 巻 (2012 年)

第 2 表 結果のまとめ

\begin{tabular}{ccccc}
\hline 重み $w_{R}$ & 総加熱量 $\left[\mathrm{MJ} / \mathrm{m}^{2}\right]$ & 飛行レンジ $[\mathrm{km}]$ & 初期経路角 $[\mathrm{deg}]$ & 総飛行時間 $[\mathrm{sec}]$ \\
\hline 0 & 171.10 & 2055.20 & -1.82 & 320 \\
\hline 0.3 & 171.90 & 2076.45 & -1.68 & 323 \\
\hline 0.32 & 172.09 & 2081.15 & -1.68 & 324 \\
\hline 0.34 & 216.15 & 3973.77 & -0.04 & 578 \\
\hline 0.36 & 220.71 & 4161.22 & -0.04 & 603 \\
\hline 0.38 & 225.75 & 4357.97 & -0.04 & 630 \\
\hline 0.40 & 243.14 & 4994.94 & -0.02 & 720 \\
\hline 0.42 & 253.95 & 5366.36 & -0.02 & 774 \\
\hline 0.44 & 262.35 & 5643.98 & -0.02 & 815 \\
\hline 0.46 & 271.28 & 5922.51 & -0.06 & 858 \\
\hline 一定経路角 & 198.09 & 2825.46 & -0.55 & 435 \\
\hline
\end{tabular}

速度の上下限を遷移している. 今回の計算ではバンク角の 制限值は設定していないが, バンク角を $90^{\circ}$ 以下とする制 限を加えて背面飛行を行わない場合の最適軌道を求めるこ とも容易に行える.

\section{4. ま と め}

一般に最適制御問題は取り扱いが難しく, 設計者の要求 をすべて満たす実用的なツールが存在しないことから誘導 制御系の設計現場において敬遠されることが多い，そこで 本論文において, 扱いや寸く有用な最適制御のツールとし て動的計画法を提案し, 再突入飛行における最適軌道を設 計した. 特に, 制御変数の数が状態変数の数よりも少ない 場合の離散化誤差の問題に取り組み, 解決する方法として, 補助制御変数法および最小誤差格子点選択法を提案した. 2 つの方法を再突入飛行の軌道最適化一応用して有效性を確 認することができた.動的計画法には計算時間が予測でき, 拘束条件への対応が容易であるという利点がある一方で計 算規模の課題が残されている. 動的計画法の欠点である「次 元の呪い」と呼ばれる課題の解決は困難としても, 計算機 の能力が大幅に向上した現在では適用範囲の限界は以前よ り広がっている. 本論文において, 再突入飛行への応用を 通して最適化計算を容易に行えることが示され，動的計画 法の実用範囲を広げることができた.
1) Bryson, A.E. and Ho, Y.C.: Applied Optimal Control, Ginn and Company, Waltham, Massachusetts, 1969, pp. 42-147.

2) 加藤寛一郎: 工学的最適制御 非線形へのアプローチ, 東京大学 出版会, 1988, pp. 77-191.

3) Betts, J. T.: Survey of Numerical Methods for Trajectory Optimization, Journal of Guidance, Control and Dynamics, 21, 2 (1998), pp. 193-207.

4) Elnagar, J. and Kazemi, M. A.: The Pseudospectral Legendre Method for Discretizing Optimal Control Problems, IEEE Transactions on Automatic Control, 40, 10 (1995), pp. 1793-1796.

5) Fahroo, F. and Ross, I. M.: Direct Optimization by a Chebyshev Pseudospectral Method, Journal of Guidance, Control and Dynamics, 25, 1 (2002), pp. 160-166.

6) 宮沢与和: 動的計画法による経路最適化と D-SEND\#2 への応用, 第 49 回飛行機シンポジウム講演集，2011，pp. 657-662.

7) Bellman, R.: Dynamic Programming, Princeton Univ. Press, Princeton, New Jersey, 1957, pp. 183-221.

8) Harpold, J. C. and Graves, C. A. Jr.: Shuttle Entry Guidance, American Astronautical Society, Anniversary Conference, 25th, Oct. 30-Nov. 2, 1978.

9) Lu, P.: Entry Guidance and Trajectory Control for Reusable Launch Vehicle, Journal of Guidance, Control and Dynamics, 20, 1 (1997), pp. 143-149.

10) Vinh, N.X.: Optimal Trajectories in Atmospheric Flight, Elsevier Scientific Publishing Company, Amsterdam, 1981, pp. 295-367.

11)加藤寛一郎: スペースプレーン, 東京大学出版会, 1989, pp. 121-137.

12) Bellman, R. and Kalaba, R., 野村弘光訳: ダイナミックプログラミ ングと現代制御理論，東京図書株式会社，1972， pp. 35-105. 